\title{
Evaluation of Caco-2 cell permeability of ritonavir nanosuspensions
}

\author{
Alptuğ Karaküçük ${ }^{1}$, Naile Öztürk² (D), Nevin Çelebi1 ${ }^{1,3}$ (D) \\ 'Gazi University, Faculty of Pharmacy, Department of Pharmaceutical Technology, Ankara, Turkey \\ ${ }^{2}$ Inonu University, Faculty of Pharmacy, Department of Pharmaceutical Technology, Malatya, Turkey \\ ${ }^{3}$ Baskent University, Faculty of Pharmacy, Department of Pharmaceutical Technology, Ankara, Turkey
}

ORCID IDs of the authors: A.K. 0000-0002-9061-2427; N.Ö. 0000-0002-7617-8433; N.Ç. 0000-0002-6402-5042

Cite this article as: Karakucuk, A., Ozturk, N., \& Celebi, N. (2020). Evaluation of Caco-2 cell permeability of ritonavir nanosuspensions. Istanbul Journal of Pharmacy, 50 (3), 251-255.

\begin{abstract}
Background and Aims: Poor aqueous solubility limits drug absorption through intestinal mucosa. Nanosuspensions with nanometer range particle size provides enhanced aqueous solubility and hence permeability. The objective of this study was to investigate the cytotoxicity and in vitro cell permeability through human adenocarcinoma (Caco-2) cells of ritonavir (RTV) nanosuspensions.

Methods: The Microfluidization method was used to prepare nanosuspensions. Particle size (PS), polydispersity index (PI) and zeta potential (ZP) values were measured as characterization. MTT test was applied to evaluate the cytotoxic effect. Caco-2 cell lines were used for transport studies with RTV coarse powder, physical mixtures and nanosuspension.

Results: Approximately $600 \mathrm{~nm}$ PS, 0.4 PDI and $22 \mathrm{mV}$ ZP values were observed for nanosuspensions. The sample groups showed no cytotoxicity on the cell lines in any RTV concentration. However, significant cytotoxic effect was determined in groups with high amounts of sodium dodecyl sulfate. The transported RTV in nanosuspension formulation enhanced by 5.3fold and 1.5-fold in comparison with RTV coarse powder and physical mixture, respectively. Rate of the transportation and also the amount of the transported RTV were improved with nanosuspension formulation.

Conclusion: Particle size reduction of RTV into nanometer size and preparing nanosuspension system was found effective to obtain enhanced cell permeability.

Keywords: Ritonavir, nanosuspension, Caco-2, permeability
\end{abstract}

\section{INTRODUCTION}

The solubility in intestinal fluids and permeability from intestinal membrane effect the drug absorption efficiency. Poor drug solubility limits dissolution and hence lower concentration gradient occurs across the intestinal mucosa (Lenhardt, Vergnault, Grenier, Scherer, \& Langguth, 2008). Nanosuspensions are colloidal systems with a particle size below $1 \mu \mathrm{m}$. The increased surface area of particles by reducing their particle size under nano meter range improves the saturation solubility and dissolution velocity (Xie, Luo, Liu, Ma, Yue, \& Yang, 2019). Hence, the poorly soluble drug may have sufficient therapeutic effects with reduced side effects and better transportation to cells of the drug molecules Karakucuk, Alptug, Teksin, Ero- glu, \& Celebi, 2019). The conventional precipitation method or top-down methods are used to prepare nanosuspensions. More preferred approaches are the top-down methods such as media milling or high pressure homogenization, which downsize the particles by high energy creating cavitation and shear forces (Tashan, Karakucuk, \& Celebi, 2019). Nanosuspensions are thermodynamically unstable system and stabilization process by using surfactant or polymer is mandatory. Steric or electrostatic stabilization can be achieved in the system with surfactant and/or polymers.

Cell and tissue culture studies are used to investigate the transport of drug from delivery system into specific cells and across specific barriers. Caco-2 cell lines demonstrate the morpho-
Address for Correspondence:

Nevin ÇELEBI, e-mail: ncelebi51@gmail.com

This work is licensed under a Creative Commons Attribution 4.0 International License.
Submitted: 13.04 .2020

Revision Requested: 03.06 .2020

Last Revision Received: 07.06.2020

Accepted: 07.07.2020

Published Online: 09.12.2020 
logical and biochemical features of adult differentiated enterocytes and goblet cells, which bring benefit to study intestinal epithelial differentiation and function (Wilson, 1990). The wellestablished Caco-2 cell monolayer system allows direct measurement of the drug fluxes across an epithelium (Lenhardt et al., 2008). They also, indicate P-gp and metabolizing enzymes to predict the absorption of orally administrated compounds ( Matsumoto, Kaifuchi, Mizuhara, Warabi, \&Watanabe, 2018).

The in vitro (Karakucuk, Celebi, \& Teksin, 2016) and in vivo studies (Karakucuk et al., 2019) were evaluated in previous studies. Therefore, this study mainly focused on the investigation of cytotoxicity and Caco-2 cell permeability of RTV nanosuspensions. Possible P-gp effect of the formulation was also examined.

\section{MATERIALS AND METHODS}

\section{Materials}

Ritonavir (RTV) was kindly gifted by Mylan Pharmaceuticals (India) and hydroxypropyl methyl cellulose (HPMC) (3 cps) was donated by Colorcon Limited (Istanbul, Turkey). Sodium dodecyl sulfate (SDS) was purchased from Merck (Darmstadt, Germany). Human epithelial colorectal adenocarcinoma cell (Caco-2, ATCC HTB 37) was obtained from ATCC. Methyl-thiazolyl tetrazolium (MTT), Hank's balanced salt solution (HBSS), and Dulbecco's modified eagle medium (DMEM) were purchased from Sigma-Aldrich (St. Louis, Missouri, USA). Other chemicals were HPLC or analytical grade.

\section{Preparation of ritonavir nanosuspensions}

RTV nanosuspensions were prepared according to previous study (Karakucuk et al., 2016). Briefly, the stabilizer solution, which was consisted of 4\% HPMC 3 cps and 0.8\% SDS was prepared. $2 \% \mathrm{w} / \mathrm{w}$ of RTV was dispersed this solution and prehomogenized for 10 minutes at 10000 rpm using ultraturrax. The pre-treatment step allowed to reduce particle size below $84 \mu \mathrm{m}$ in regard to $\mathrm{d} 99$. It is because $84 \mu \mathrm{m}$ Z-type chamber was used to perform interaction of particles on microfluidization. Then, the coarse suspension was processed by jet stream homogenizer (Microfluidizer ${ }^{\circledast}$ Processors, Westwood, Massachusetts, USA) under high pressure (30 000 psi). After 20 cycles of homogenization nanosuspensions were obtained. The process continued with lyophilization, and nanosuspensions were freeze-dried to fill in the capsules as dosage form and also improve physical stability. For the lyophilization process approximately $2 \mathrm{~mL}$ of the nanosuspensions were frozen at $-80^{\circ} \mathrm{C}$ for $2 \mathrm{~h}$. Freeze-dry process was performed at $-50{ }^{\circ} \mathrm{C}, 0.021 \mathrm{mbar}$ for 40 h using Christ Alpha 1-2 LD Freeze Dryer.

\section{Cell culture studies}

The Caco-2 cells were used to investigate permeability of coarse RTV and compare permeability values with nanosuspensions. The Caco-2 cells were cultured using DMEM with L-glutamine, supplemented with fetal bovine serum $(10 \%, v / v)$ and penicillin/ streptomycin (50 $\mathrm{JU} / \mathrm{mL}$ and $50 \mu \mathrm{g} / \mathrm{mL}$, respectively) in a humidified incubator at $37{ }^{\circ} \mathrm{C}$ in air containing $5 \% \mathrm{CO}_{2}$.

\section{In vitro cytotoxicity}

Before performing permeability studies, the effect of the formulations on cell viability of Caco-2 cells was investigated by
MTT assay. Cells were seeded at a density of $5 \times 10^{3}$ cells per well to 96-well plate and incubated overnight and then the drug solution and formulations (RTV coarse powder, physical mixtures, stabilizer mixtures and nanosuspension) were added to the wells at different concentrations and incubated for 4 hours. DMSO was used to solubilize the drug; therefore, DMSO solution (0.25-4\%) was also applied as control. After incubation period, $25 \mu \mathrm{L}$ MTT solution was added to wells and incubated for 4 hours. Then the medium was removed and $200 \mu \mathrm{L}$ of DMSO was added to wells to solubilize the formazan crystals and optical density of wells was measured at $570 \mathrm{~nm}$.

\section{In vitro permeability studies}

For permeability studies, cell monolayers were prepared by seeding harvested cells onto inserts $(12 \mathrm{~mm}$ Snapwell Insert with $0.4 \mu \mathrm{m}$ pore) at a density of $7 \times 10^{4}$ cells per well. After 21 days of culturing (changing the medium every other day), TEER values were measured to determine monolayer integrity. Apical to basolateral transport studies were conducted after the application of formulations in Hank's Balanced Salt Solution (HBSS $\mathrm{pH}$ 7.4) to the donor compartment $(0.5 \mathrm{~mL})$. RTV bulk powder, nanosuspension, and physical mixtures of stabilizers with or without RTV were used as samples (RTV concentration was 50 $\mathrm{mg} / \mathrm{mL}$ in all RTV containing samples, $\mathrm{n}=6)$. At predetermined time intervals (30, 60, 90,120 and 240 mins), $0.5 \mathrm{~mL}$ sample was withdrawn from basolateral compartment and then fresh medium (HBSS) was added to the wells. Samples were isolated from the receiver compartment $(1.5 \mathrm{~mL}) 4$ hours after the incubation. The apparent permeability coefficients $\left(P_{a p p}, \mathrm{~cm} / \mathrm{sn}\right)$ were calculated according to equation below (Eq. 1):

$$
P a p p=\frac{d Q / d t}{A .60 . C 0}
$$

Where $\mathrm{dQ} / \mathrm{dt}$ ( $\mu \mathrm{mol} /$ L.min) is the cumulative amount of RTV which has been transported over the membrane, $\mathrm{A}\left(1.12 \mathrm{~cm}^{2}\right)$ is the surface area of the inserts and $C_{0}(\mu \mathrm{mol} / \mathrm{L})$ is the initial concentration of the RTV on the donor site.

The HPLC method was used to analyze of the samples at 239 $\mathrm{nm}$, which was validated according to accuracy, precision, repeatability, specificity, detection limit, quantitation limit, linearity, and range. The HPLC instrument was HP 1050 series and the C18 RP column ( $250 \mathrm{~mm} \times 4.6 \mathrm{~mm}, 5 \mu \mathrm{m}$ ) was equipped as an analytical column. The mobile phase was consisted of acetonitrile: $0.05 \mathrm{M}$ phosphoric acid (55:45 v/v). Injection volume was $25 \mu \mathrm{L}$ and flow rate was $1 \mathrm{~mL} / \mathrm{min}$. Retention time of RTV was 11-12 minutes.

\section{Statistical analysis}

Statistical evaluation was performed with one-way ANOVA followed Tukey HSD Post hoc test at the significance level of 0.05 . Mean \pm standard deviation was provided for all data.

\section{RESULTS AND DISCUSSION}

\section{Preparation of ritonavir nanosuspensions}

The main process factors for the microfluidization method that effect quality of final nanosuspensions are the chamber type and size, temperature, homogenization cycle, and pressure 
(Salazar, Heinzerling, Müller, \& Möschwitzer, 2011). Additionally, formulation parameters such as physicochemical properties of the drug, amount of the drug, type and amount of the stabilizers should be considered and optimized (Van Eerdenbrugh, Van den Mooter, \& Augustijns, 2008). In this study, 84 mm Ztype chamber was used to obtain nanosuspensions, which is the appropriate size and type for microfluidization. Temperature was controlled during the study. 20 homogenization cycles were applied. The well-known stabilizers, which were HPMC and SDS were used to stabilize the nanosuspensions. $2 \%$ of RTV was added in the formulations considering the final oral dose for capsule dosage form. The nanosuspensions were obtained approximately $600 \mathrm{~nm}$ PS, 0.4 PDI and -22 mV ZP values. The final RTV nanosuspensions were found physically stable for 30 days of storage time at room temperature. Also, physicochemical properties of RTV were preserved according to differential calorimetry and $\mathrm{X}$-ray diffraction results which is shown in previous study (Karakucuk et al., 2016).

\section{Caco-2 cell viability and permeability}

Monolayer integrity of Caco-2 cell was shown with TEER values of 500-1000 ohm.cm². MTT assay was conducted to understand the in vitro toxicity of the RTV in different formulations. Cell viability (\%) was observed after the interaction between Caco-2 cells and RTV formulations for 4 hours. Cytotoxicity was not observed by using RTV coarse powder even in the highest dose which was $400 \mu \mathrm{g}$. The cytotoxicity was resulted from the formulations with SDS either in the existence of RTV or not. In the findings from different concentrations, the increased use of SDS caused toxicity on Caco-2 cells. Nanosuspension and the other formulations had no cytotoxic effect at the $50 \mu \mathrm{g}$ dose used in the permeability study (Figure 1). Cell viability results were above $100 \%$ for some treatment groups, especially for coarse RTV powder. MTT is converted to formazan by viable cells with active metabolism so MTT reduction indicates viable cell metabolism rather than cell proliferation (Riss et al., 2016). Thus our results suggest that increasing RTV concentration, increases cellular metabolic activity of Caco-2 cells.

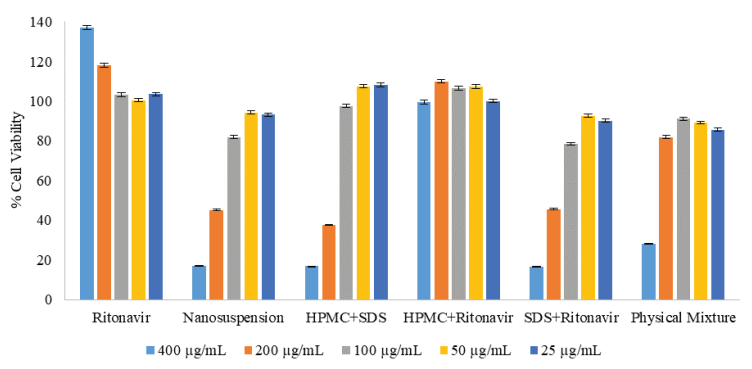

Figure 1. Cell viabilities (\%) for the sample groups $(n=6)$.

The Permeability value of coarse RTV and physical mixture were determined $1.57 \times 10^{-5} \mathrm{~cm} / \mathrm{s}$ and $5.75 \times 10^{-5} \mathrm{~cm} / \mathrm{s}$, respectively (Figure 2). The permeability value of coarse RTV was found similar to the literature which is at about $2 \times 10^{-5} \mathrm{~cm} / \mathrm{s}$ (Alsenz, Steffen, \& Alex, 1998; Holmstock, Annaert, \& Augustijns, 2012). As the permeability value of RTV was found above $1 \times 10^{-5} \mathrm{~cm} / \mathrm{s}$, it was concluded that the RTV has high permeability property which means RTV belongs to BCS Class II drug with this per- meability value. The literature data have also proven this result (Chowdary, Annamma Devi, \& Dhanalakshmi, 2012; Sinha, Ali, Baboota, Ahuja, Kumar, \& Ali, 2010).

The permeability value of nanosuspension was increased and was found $8.38 \times 10^{-5} \mathrm{~cm} / \mathrm{s}$ (Figure 2). The permeability value of nanosuspension was higher than the other physical mixtures $(p<0.05)$. The increment of the permeability value of nanosuspension can be resulted from decreasing particle size under micrometer scale. Beside the nanometer particle size values, nanosuspension was prepared by SDS and it is known that SDS can inhibit P-glycoprotein (P-gp) which can result in permeability enhancement (Koga, Ohyashiki, Murakami, \& Kawashima, 2000; Miller, Batrakova, \& Kabanov, 1999; Rege, Yu Lawrence, Hussain, \& Polli, 2001). It is also known that RTV is p-gp substrate by itself Schmitt, Kaeser, Riek, Bech, \& Kreuzer, 2010) and studies showed that RTV induced protein expression of p-gp and increased cellular drug exclusion ( Perloff, Von Moltke, Marchand, \& Greenblatt, 2001). Using RTV as drug efflux transporter is a strategy to improve intracellular concentration of drug molecules (Janneh, Jones, Chandler, Owen, \& Khoo, 2007).

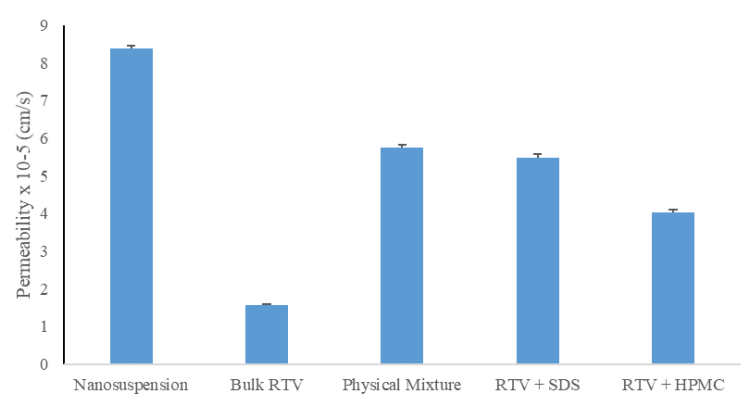

Figure 2. Permeability values of different groups $(n=6)$.

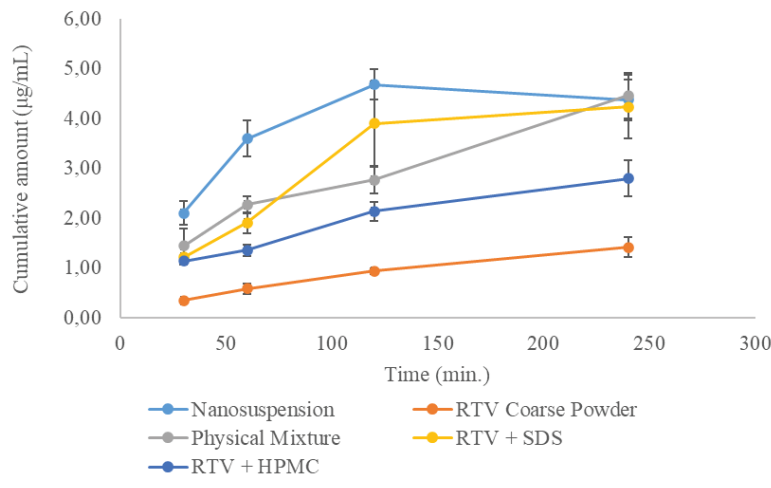

Figure 3. Cumulative amount of RTV in basolateral membrane $(n=6)$.

Cumulative transported RTV amount to the basolateral membrane is given in Figure 3. No further drug transportation was observed after 120 minutes by nanosuspension exposure.

Even the nanosuspension showed faster drug transport, the cumulative drug transported at the end of the assay was similar among nanosuspension, physical mixture, and RTV with SDS formulations. SDS was provided P-gp inhibition which was resulted in an increase in RTV amount in basolateral 
membrane. However, RTV coarse powder showed slower and lower drug transport to the basolateral membrane even in comparison with RTV and HPMC mixture. As a polymer, HPMC possessing p-gp inhibiting activity (Rehman et al., 2017), this could also explain that HPMC might be caused P-gp inhibition. It is know that inhibition or induction of functionality of P-gp can affect the pharmacokinetics, efficacy, safety, or tissue levels (Matsumoto et al., 2018).

\section{CONCLUSION}

The microfluidization method was found an effective method to develop nanosuspension formulation regarding to fewer process parameters and easy for scale-up. Neither nanometer range RSV nor using stabilizer combination did not show cytotoxic effect on Caco-2 cells at desired concentration. The nanosuspensions with particle size below $1000 \mathrm{~nm}$ showed enhanced permeability through Caco-2 cells due to increased saturation solubility. It could also be said that stabilizers showed P-gp effect, which resulted in improved cumulative drug transport. It is concluded that beside nanosuspensions being beneficial to improve saturation solubility, dissolution and bioavailability, they also increase the cell permeability of poorly soluble drugs.

Peer-review: Externally peer-reviewed.

Informed Consent: Written consent was obtained from the participants.

Author Contributions: Conception/Design of Study- A.K., N.Ö., N.Ç.; Data Acquisition- A.K., N.Ö., N.Ç.; Data Analysis/Interpretation- A.K., N.Ö., N.Ç.; Drafting Manuscript- A.K., N.Ö., N.Ç.; Critical Revision of ManuscriptA.K., N.Ö., N.Ç.; Final Approval and Accountability- A.K., N.Ö., N.Ç.; Technical or Material Support- A.K., N.Ö., N.Ç.; Supervision- A.K., N.Ö., N.Ç.

Conflict of Interest: The authors have no conflict of interest to declare.

Financial Disclosure: This study was supported by a grant from The Scientific and Technological Research Council of Turkey. (Project No: 1135842, TUBITAK)

\section{REFERENCES}

- Alsenz, J., Steffen, H., \& Alex, R. (1998). Active apical secretory efflux of the HIV protease inhibitors saquinavir and ritonavir in Caco-2 cell monolayers. Pharmaceutical Research, 15(3), 423-428. https://doi.org/10.1023/A:1011924314899

- Chowdary, K. P. R., Annamma Devi, D. G., \& Dhanalakshmi, K. (2012). A factorial study on enhancement of solubility and dissolution rate of ibuprofen by hydroxy propyl $\beta$ cyclodextrin and solutol hs15. International Journal of Pharmaceutical Sciences Review and Research, 2(4), 1-7.

- Holmstock, N., Annaert, P., \& Augustijns, P. (2012). Boosting of HIV protease inhibitors by ritonavir in the intestine: The relative role of cytochrome P450 and P-glycoprotein inhibition based on Caco-2 monolayers versus in situ intestinal perfusion in mice. Drug Metabolism and Disposition, 40(8), 1473-1477. https://doi. org/10.1124/dmd.112.044677

- J Janneh, O., Jones, E., Chandler, B., Owen, A., \& Khoo, S. H. (2007). Inhibition of P-glycoprotein and multidrug resistance-associated proteins modulates the intracellular concentration of lopinavir in cultured CD4 T cells and primary human lymphocytes. Journal of Antimicrobial Chemotherapy, 60(5), 987-993. https://doi. org/10.1093/jac/dkm353
Karakucuk, A., Celebi, N., \& Teksin, Z. S. (2016). Preparation of ritonavir nanosuspensions by microfluidization using polymeric stabilizers: I. A Design of Experiment approach. European Journal of Pharmaceutical Sciences, 95, 111-121. https://doi.org/10.1016/j. ejps.2016.05.010

- Karakucuk, Alptug, Teksin, Z. S., Eroglu, H., \& Celebi, N. (2019). Evaluation of improved oral bioavailability of ritonavir nanosuspension. European Journal of Pharmaceutical Sciences, 131 (February), 153-158. https://doi.org/10.1016/j.ejps.2019.02.028

- Koga, K., Ohyashiki, T., Murakami, M., \& Kawashima, S. (2000). Modification of ceftibuten transport by the addition of non-ionic surfactants. European Journal of Pharmaceutics and Biopharmaceutics, 49(1), 17-25. https://doi.org/10.1016/S0939-6411(99)00059-4 - Lenhardt, T., Vergnault, G., Grenier, P., Scherer, D., \& Langguth, P. (2008). Evaluation of nanosuspensions for absorption enhancement of poorly soluble drugs: In vitro transport studies across intestinal epithelial monolayers. AAPS Journal, 10(3), 435-438. https://doi.org/10.1208/s12248-008-9050-7

- Matsumoto, T., Kaifuchi, N., Mizuhara, Y., Warabi, E., \& Watanabe, J. (2018). Use of a Caco-2 permeability assay to evaluate the effects of several Kampo medicines on the drug transporter P-glycoprotein. Journal of Natural Medicines, 72(4), 897-904. https://doi. org/10.1007/s11418-018-1222-x

- $\quad$ Miller, D. W., Batrakova, E. V, \& Kabanov, A. V. (1999). Inhibition of multidrug resistance-associated protein (MRP) functional activity with pluronic block copolymers. Pharmaceutical Research, 16(3), 396-401. https://doi.org/10.1023/A:1018873702411

Perloff, M. D., Von Moltke, L. L., Marchand, J. E., \& Greenblatt, D. J. (2001). Ritonavir induces P-glycoprotein expression, multidrug resistance-associated protein (MRP1) expression, and drug transporter-mediated activity in a human intestinal cell line. Journal of Pharmaceutical Sciences, 90(11), 1829-1837. https://doi. org/10.1002/jps.1133

- $\quad$ Rege, B. D., Yu Lawrence, X., Hussain, A. S., \& Polli, J. E. (2001). Effect of common excipients on Caco-2 transport of low-permeability drugs. Journal of Pharmaceutical Sciences, 90(11), 1776-1786. https://doi.org/10.1002/jps.1127

- Rehman, S., Nabi, B., Fazil, M., Khan, S., Bari, N. K., Singh, R., Ahmad, S., Kumar, V., Baboota, S., \& Ali, J. (2017). Role of P-Glycoprotein Inhibitors in the Bioavailability Enhancement of Solid Dispersion of Darunavir. BioMed Research International, 2017, 1-17. https://doi. org/10.1155/2017/8274927

- $\quad$ Riss, T. L., Moravec, R. A., Niles, A. L., Duellman, S., Benink, H. A., Worzella, T. J., \& Minor, L. (2016). Cell viability assays. In Assay Guidance Manual [Internet]. Eli Lilly \& Company and the National Center for Advancing Translational Sciences.

- Salazar, J., Heinzerling, O., Müller, R. H., \& Möschwitzer, J. P. (2011). Process optimization of a novel production method for nanosuspensions using design of experiments (DoE). International Journal of Pharmaceutics, 420(2), 395-403. https://doi.org/10.1016/j. ijpharm.2011.09.003

- Schmitt, C., Kaeser, B., Riek, M., Bech, N., \& Kreuzer, C. (2010). Effect of saquinavir/ritonavir on P-glycoprotein activity in healthy volunteers using digoxin as a probe. International Journal of Clinical Pharmacology and Therapeutics, 48(3), 192-199. https://doi. org/10.5414/CPP48192

- $\quad$ Sinha, S., Ali, M., Baboota, S., Ahuja, A., Kumar, A., \& Ali, J. (2010). Solid dispersion as an approach for bioavailability enhancement of poorly water-soluble drug ritonavir. AAPS PharmSciTech, 11(2), 518-527. https://doi.org/10.1208/s12249-010-9404-1

- Tashan, E., Karakucuk, A., \& Celebi, N. (2019). Optimization and in vitro evaluation of ziprasidone nanosuspensions produced by a top-down approach. Journal of Drug Delivery Science and Technology, 52(March), 37-45. https://doi.org/10.1016/j.jddst.2019.04.024 
- Van Eerdenbrugh, B., Van den Mooter, G., \& Augustijns, P. (2008). Top-down production of drug nanocrystals: Nanosuspension stabilization, miniaturization and transformation into solid products. International Journal of Pharmaceutics, 364(1), 64-75. https://doi. org/10.1016/j.ijpharm.2008.07.023

- Wilson, G. (1990). Cell culture techniques for the study of drug transport. European Journal of Drug Metabolism and Pharmacokinetics, 15(2), 159-163. https://doi.org/10.1007/BF03190199
Xie, J., Luo, Y., Liu, Y., Ma, Y., Yue, P., \& Yang, M. (2019). Novel redispersible nanosuspensions stabilized by co-processed nanocrystalline cellulose-Sodium carboxymethyl starch for enhancing dissolution and oral bioavailability of baicalin. International Journal of Nanomedicine, 14, 353-369. https://doi.org/10.2147/ IJN.S184374 